\title{
What Did We Get When We Got Sex?
}

\author{
R. Stewart Mayers \\ Southeastern Oklahoma State University \\ Thomas W. Harvey \\ Lamar University \\ C. Todd Williams \\ Southeastern Oklahoma State University
}

\begin{abstract}
The purpose of this paper is to examine how the federal courts have interpreted the word "sex" in the context of Title VII of the 1964 Civil Rights Act. The discussion begins with a brief legislative history and then discusses the development of federal case law relevant to Title VII's command concerning sex discrimination. This discussion is divided into three sections: early court opinions of the pre-1989 case law, the Supreme Court's landmark Price Waterhouse v. Hopkins decision in 1989, and the evolving views of the federal courts as evidenced in the post-1989 case law. Finally, the ramifications of, and recommendations based on current understandings of the word "sex" in Title VII law, particularly in light of the Court's decision in Bostock v. Clayton County (2020) are offered.
\end{abstract}

Keywords: Title VII, Civil Rights Act, Supreme Court

\section{INTRODUCTION}

"What did we get when we got sex?" This question was posed by Federal District Judge John Grady in his discussion of the legislative history of Title VII of the Civil Rights Act (1964) in Ulane v. Eastern Airlines. In Ulane (1984), a male-to-female, transsexual pilot for Eastern Airlines was terminated after sexual reassignment surgery. Believing discrimination based on transsexuality to be protected under Title VII, the plaintiff filed suit. Title VII provides that:

"It shall be an unlawful employment practice for an employer to fail or refuse to hire or to discharge any individual or otherwise discriminate against any individual with respect to his compensation, terms or conditions or privileges of employment because of such individual's race, color, religion, sex, or national origin" (Civil Rights Act, 1964).

The words "because of . . . sex" have little legislative history through which their meaning may be deduced. The primary focus of the Civil Rights Act was to address racial discrimination. "Sex" was added by floor amendment one day prior to receiving approval in the House of Representatives as a "gambit of a Southern senator [Howard W. Smith of Virginia] who sought thereby to scuttle the whole Civil Rights Act" (1964). 
Early case law followed a narrow interpretation of the phrase "because of . . sex." The federal court for the Northern District of California opined in Voyles v. Ralph Davies Medical Center (1975) that "employment discrimination based on one's transsexualism is not, nor was intended by the Congress to be, proscribed by Title VII of the Civil Rights Act of 1964" (p. 457). In Sommers v. Budget Marketing (1982), the court reasoned, "because Congress has not shown an intention to protect transsexuals, we hold that discrimination based on one's transsexualism does not fall within the protective purview of the [Civil Rights] Act” (p. 750).

In Price Waterhouse v. Hopkins (1989), the United States Supreme Court held that discrimination based on sex stereotyping violated Title VII of the Civil Rights Act and that employers had to prove, "by a preponderance of the evidence, that it would have made the same decision even if it had not taken . . gender into account" (p. 228). Following Price Waterhouse, courts began considering a more expansive view of sex discrimination under Title VII.

A fire fighter in Salem, Ohio, filed suit in response to his termination, claiming the city's decision to fire him from the fire department was due to his Gender Identity Disorder and its treatment, including Smith's public presentation as a female, although biologically still a male (Smith vs. City of Salem, Ohio, 2004). The Smith court, concluding the Supreme Court's holding in Price Waterhouse had "eviscerated" (p. 573) previous case law, reversed a district court's holding that Title VII provided no protection from discrimination for transsexuals. In Schroer v. Billington (2008), an applicant for a position as a documents analyst at the Library of Congress filed suit, claiming discrimination on the basis of sex when the applicant, a male-to-female transsexual, informed the interviewer of her plans to have sexual reassignment surgery in the near future. The federal district court for the District of Columbia denied summary judgment to Billington, asserting that there could be circumstances under which Title VII could provide protection against discrimination for transsexuals.

Whether the person in question is a fire fighter, document analyst, or bus driver, the question of whether or not "because of sex" includes transsexuals is still a murky legal area. This paper will explore case law, both pre- and post- Price Waterhouse as well as recent EEOC and SCOTUS decisions to bring some clarity to this area of the law.

\section{PRE-PRICE WATERHOUSE CASE LAW}

Case law prior to Price Waterhouse generally accepted a narrow interpretation of the phrase "because of . . sex" when analyzing Title VII sex discrimination cases. In Voyles v. Ralph Davies Medical Center (1975), Charles Franklin Voyes, a hemodialysis technician for the Ralph Davies Medical Center, informed the Center's director of personnel his intention to undergo sexual reassignment surgery and become Carol Lynn Voyles. Shortly thereafter, Voyles was terminated. Voyles admitted the possibility of adverse reactions by his patients to his new gender and the Center admitted the reason for Voyles's termination was Voyles's intended sexual reassignment surgery. The court opined that in Title VII "No mention is made of change of sex or of sexual preference" $(1975, \mathrm{p} .457)$ and that legislative history nor case law "nowhere indicate that 'sex' discrimination was meant to embrace 'transsexual' discrimination." The court went further in its description of the legislative history of Title VII. The court wrote, that "Situations involving transsexuals, homosexuals, or bi-sexuals were simply not considered, and from this void the Court is not permitted to fashion its own judicial interdictions" (1975, p. 457).

Michael D. Powell, legally and biologically a male, was living as a female in anticipation of undergoing sexual reassignment surgery. While presenting as a female and using the name Sharon, Powell applied for a job as a waitress at Read's in Baltimore, Maryland. Powell was terminated on the first day of employment allegedly because the woman Powell had replaced had returned. However, Powell claimed the termination occurred because information that Powell was still legally and biologically a male was given to the manager by persons who knew Powell prior to his presentation as a female. Powell filed suit (Powell vs. Read's, Inc. 1977), claiming discrimination on the basis of sex under Title VII. The court opined that a "reading of the statute [Title VII] to cover plaintiff's grievance would be impermissibly contrived and inconsistent with the plain meaning of the words" (1977, p.371). 
Later that same year, Ramona Holloway, a male-to-female transgendered person, appealed her termination by Arthur Andersen and Company because of her transgendered status (Holloway v. Arthur Andersen \& Co., 1977). Despite being given a pay raise and a promotion, Holloway was terminated from her job when she informed her employer of her intent to have sexual reassignment surgery. An official with Arthur Andersen suggested Holloway "would be happier at a new job where her transsexualism would be unknown" (1977, p.661). Holloway argued that for Congress to exclude transsexuals from Title VII protection would be tantamount to a violation of the equal protection clause and her case should be decided based on the "cardinal principle" espoused by Justice Louis Brandeis that requires statutes to be construed "so that constitutional questions may be avoided if at all possible" (1977, p. 663).

In Holloway (1977), a three-judge panel of the Ninth Circuit rendered a split decision that refused to recognize Title VII protection for transsexual persons. The court held that transsexuals are not a "suspect class." According to the U.S. Supreme Court, "suspect class" refers to individuals who are historically discriminated against, possessing an immutable trait, or powerless to protect themselves through the political process (Frontiero v. Richardson, 1973; Graham v. Richardson, 1971; Lyng v. Castillo, 1986). As a result, Title VII protection did not extend to transsexuals.

Audra Sommers, formerly known as Timothy Cornish, applied for and was hired in a clerical position with Budget Marketing, Incorporated, in April of 1980. Two days later, Sommers's employment was terminated because Budget believed she misrepresented her gender (claiming to be anatomically female) during the interview process. The company claimed this created a significant disruption in the operation of their business because many of their female employees threatened to quit if Sommers was allowed to use the women's restroom. To clarify Sommers's claim, the district court requested her to amend her original complaint to clarify whether she was claiming discrimination because "she was male, female, or transsexual, and whether she had ... undergone sexual conversion surgery" (Sommers v. Budget Marketing, Inc., 1982, p. 749). The court reasoned, "because Congress has not shown an intention to protect transsexuals, we hold that discrimination based on one's transsexualism does not fall within the protective purview of the [Civil Rights] Act" (1982, p. 750).

The narrow interpretation of Title VII protection against discrimination on the basis of sex was further reinforced by the $7^{\text {th }}$ Circuit Court of Appeals in Ulane v. Eastern Airlines (1984, p. 712). Kenneth Ulane, a decorated army pilot and veteran of Vietnam, was hired as a pilot by Eastern Airlines in 1968. In 1979, Ulane was diagnosed as a transsexual and sought psychiatric treatment. By 1980, Ulane had completed her transition and had become Karen Frances Ulane, where upon the State of Illinois issued her a revised birth certificate. Upon returning to work following surgery, Ulane was terminated (1984, pp. 1082-1083).

In Ulane, the trial court judge held that sex was not merely a matter of chromosomes; sex was both a physical matter and a psychological one and ordered the reinstatement of Ulane with back pay and seniority. In reversing the finding of the trial court, the appellate panel held that Congressional intent, and not biology or psychology prevails; therefore, Title VII offers no protection to transsexual persons (1984, p. 1084). By the mid-1980s, three United States Circuit Courts of Appeals (Seventh, Eighth, and Ninth) agreed that a new or broader legal definition of sex should come from Congress and not the courts $(1984, \mathrm{p} .1086)$.

\section{PRICE WATERHOUSE V. HOPKINS (1989)}

A shift in the judicial interpretation of "discrimination on the basis of sex" began to surface with the Supreme Court's holding in Price Waterhouse v. Hopkins (1989). Ann Hopkins, a senior manager in an office of the accounting firm of Price Waterhouse, had worked in the firm's Washington, D.C., office for five years when the partners in that office proposed her for partnership in the firm. At that time, less than $1 \%$ of the Price Waterhouse partners were women (7 out of 662). Hopkins was the only woman - out of 88 candidates - proposed for partnership that year (1982). Hopkins was one of 20 candidates whose applications for partnership were "held" for subsequent consideration the following year (1989, p. 233).

In the record before the trial court, Hopkins was described as "an outstanding professional," a person of "strong character, independence and integrity," and "strong and forthright, very productive, energetic and creative" (1989, p. 234). Hopkins's work in securing a \$25 million dollar contract from the U.S. 
Department of State was described as "an outstanding performance" that was "virtually at the partner level" $(1989$, p. 233). However, the record before the trial court also included troubling comments such as Hopkins "overcompensated for being a woman" (1989, p. 235). One partner had advised Hopkins take "a course at charm school" while another advised her to "walk more femininely, talk more femininely, dress more femininely, wear make-up, have her hair styled, and wear jewelry" (1989, p. 235).

The trial court held that Hopkins had been discriminated against based on her gender and found for Hopkins on the question of liability. The United States Court of Appeals for the District of Columbia affirmed. Both courts' holdings required Price Waterhouse to prove by clear and convincing evidence that the firm would have made the same decision in the absence of the consideration of forbidden criteria of Hopkins's gender, and that Price Waterhouse had not met this burden (1985, p. 1109; 1987, p. 458). The U.S. Supreme Court then granted certiorari.

The Supreme Court's review focused attention on the liability phase of the litigation and what standard of proof should be required of Price Waterhouse in order to escape liability. The lower courts held that Price Waterhouse had to prove "by clear and convincing evidence" that absent the influence of Hopkins's gender, partners at Price Waterhouse would have reached the same decision regarding her application for partnership (1989, p. 230). A plurality of the U.S. Supreme Court reversed the lower courts' decision and remanded the case to the district court. The Supreme Court held that the appropriate standard for liability required Price Waterhouse to prove "by a preponderance of the evidence that it would have made the same decision in the absence of the discrimination" (1989, p. 228).

Perhaps as important as the Supreme Court's announcement of the appropriate burden of proof was the Court's discussion of sexual stereotype. In its brief submitted to the Court, Price Waterhouse seemed to be aware of the possible issues surrounding the use of sexual stereotypes by some of its partners. According to the Court, "... the placement by Price Waterhouse of "sex stereotyping" in quotation marks throughout its brief seems to us an insinuation either that such stereotyping was not present in the case or that it lacks legal relevance. We reject both possibilities" (1989, p. 250). The court went further: “. . . we are beyond the day when an employer could evaluate employees by assuming or insisting that they match the stereotype associated with their group" (1989, p. 251). Finally, the Court seemed to open the door to a broader interpretation of Title VII protection when it stated, "Congress intended to strike at the entire spectrum at the entire spectrum of disparate treatment of men and women resulting from sex stereotypes" (1989, p. 250). Much of the post-Price Waterhouse case law seems to support this notion.

\section{POST-PRICE WATERHOUSE CASE LAW}

The Supreme Court's expanded view of Title VII protection based on sex stereotypes was not immediately embraced by federal courts. In Etsitty v. Utah Transit Authority (2007), the Court of Appeals for the $10^{\text {th }}$ Circuit held that Title VII discrimination did not extend to the transgendered. Krystal Etsitty, a transgendered individual who was diagnosed with gender identity disordered, believed herself to be female despite being born with a male body. In October 2001, Etsitty was hired by the Utah Transit Authority as a bus driver, assigned to relieve regular drivers who are sick or on vacation. During this time Etsitty described herself as a "pre-operative transsexual." She was taking female hormones despite her presenting in her clothing and restroom usage as a male. Shortly after being hired, Etsitty informed her supervisor of her transsexual status. Another supervisor, Betty Shirley, confronted Etsitty's supervisor about a rumor about an employee who going through a sex change. Shirley expressed concern about which restroom Etsitty would use, either in the transit authority's facility or along a bus route. Shirley contacted the Human Resources department and a meeting with Etsitty was scheduled (2007, p. 1215-1217).

During the meeting with Human Resources, Etsitty confirmed she was taking female hormones, but still had male gentalia. Shirley repeated her concern about Etsitty's restroom usage, particularly away from the transit authority's building. As a fill-in driver, Etistty would drive a variety of routes requiring her to use restrooms along the way, many in local businesses. Based on this concern, Etsitty was terminated. Shirley indicated that Etsitty would be eligible for re-employment with the transit authority following her sex reassignment surgery (2007, p. 1217). 
The Etsitty court began its analysis stating that to that point (2005), no federal court had found that Title VII discrimination protection extended to transsexuals and that Etsitty claimed she was discriminated against based on sex stereotyping, not her transsexual status, meaning the Supreme Court's holding in Price Waterhouse controlled. The Etsitty court disagreed, holding Congress never intended to identify transsexuals as a protected class; therefore, they were not entitled to Title VII protection. The court reasoned that the transit authority did not discriminate against Etsitty based on sex stereotypes (making Price Waterhouse not applicable), but only required her to "conform to the accepted principles established for gender-distinct public restrooms" (2007, p. 1224). Summary judgment was granted to the transit authority. Etsitty stands in stark contrast to more current post-Price Waterhouse Title VII case law.

Jimmie Smith (2004) was a veteran member of the Salem, Ohio Fire Department, in which he held the rank of lieutenant. Seven years into his service with the department, Smith was diagnosed with Gender Identity Disorder (GID) and began treatment. As a result of his treatment, Smith began "expressing a more feminine appearance on a fulltime basis-including at work" (2004, p. 568). After Smith's coworkers began questioning him about the changes, he spoke with his immediate supervisor, Thomas Eastek. Smith discussed his GID diagnosis and that treatment most likely would culminate in surgical transformation from male to female. Smith stated the purpose of this meeting was to "clear up" any questions Eastek might have and to ask Eastek to address Smith's coworkers to alleviate the tension in the workplace. Smith also extracted a promise from Eastek that he would divulge the contents of the conversation to his superiors (2004, p. 568). Eastek immediately informed Walter Greenamyer, chief of the department, about Smith's condition.

Chief Greenamyer met with the city of Salem's legal counsel "with the intension of using Smith's transsexualism and its manifestations as a basis for terminating his employment." In a meeting with the city's executive body, a plan was devised under which Smith would be required by the Salem Civil Service Commission to submit to a battery of psychological tests. The hope was that either Smith would resign or refuse to undergo the tests, in which case he could be terminated for insubordination (2004, p. 568-569).

Smith filed suit against the City of Salem, claiming a violation of his rights under Title VII and a violation of his privacy rights under state law. The district court dismissed Smith's claims and he filed an appealed. The Court of Appeals held the district court erred because it relied "on a series of pre-Price Waterhouse cases from other federal appellate courts holding that transsexuals are not entitled to Title VII protection because Congress . . . never considered nor intended that [Title VII] applied to anything other than the traditional concept of sex" (2004, p. 572).

Furthering a broader interpretation of Title VII's protection, the Federal District Court for the District of Columbia decided Schroer v. James H. Billington, Librarian of Congress (2008). Schroer, a male-tofemale transsexual, sued the Library of Congress claiming discrimination based on sex. Schroer applied for a job analyzing documents pertaining to terrorism, an area in which he served with distinction in the armed forces. Genetically male and named David John Schroer at birth, Schroer was diagnosed with gender dysphoria, a disjunction between one's gender identity and anatomical sex (2008, p. 295). As David J. Schroer, and attired as a male, the plaintiff attended the job interview but at the time, did not disclosed her transsexualism. Several days later, Charlotte Preece, an employee of the Library of Congress who was serving on the hiring committee, called Schroer to inform her she was on the "short list" and requested supplementary materials to complete Schroer's application, including writing samples. Later, Preece called Schroer to offer her the job and asked if she would be willing to accept the job. After gaining assurance that she would receive pay comparable to her current job in the private sector, Schroer accepted the position. A few days later, Schroer contacted Preece to request a lunch meeting (2008, p. 296).

At the lunch meeting, Schroer disclosed her transsexualism and that she would begin work as Diane (presenting completely as a female), and not David. Preece's initial reaction was to ask Schroer why she would do such a thing. Schroer responded that it was not a choice, and that her treatment would not require her to miss time at work. Necessary treatment could be done during vacation time. Preece asked several questions about whether or not Schroer's name should be changed on her application materials and also raised concerns about Schroer's ability to obtain security clearances necessary for the job. Schroer responded that several of her transgendered friends had obtained security clearances, so this issue should 
present no problem for her. Schroer then showed Preece pictures of herself, dressed as a woman. Later, Preece would describe these photos as "a man in women's clothing" (2008, p. 297). Preece concluded the meeting by stating, "Well, you've given me a lot to think about. I'll be in touch" (2008, p. 295-297).

After a series of meetings with various officials within the Library of Congress, the decision was made to rescind the offer to Schroer and Preece circulated a draft email to Schroer that related 5 specific reasons for rescinding the offer, most of which centered on the question of whether "David Schroer's" clearance would be applicable to "Diane Schroer." Later, a different email, asserting Schroer was "not a good fit" (2008, p. 299) for the position was sent to Schroer. Schroer filed suit in federal district court, claiming discrimination on the basis of sex in violation of Title VII of the Civil Rights Act (1964). Alternatively, Schroer claimed Preece's action violated the Equal Protection Clause of the United States Constitution and the Library of Congress Act (1994).

At trial, Preece testified that hiring Schroer raised five concerns for her:

1. Would Schroer, as a woman, be able to maintain her contacts in the military?

2. Would Schroer be credible as a witness before Congress?

3. Since Schroer had not been forthcoming at the beginning of the interview process about her transsexual status, would she be a trustworthy employee?

4. Schroer's transition to being a woman would distract her from her job.

5. Would Schroer, as a woman, be able to maintain the security clearances she held as a man? (2008, p. 297-298)

Preece's reasoning was based on her research into the Adjudication Guidelines and the Adjudication Desk Reference. These sources stated that sexual disorders could potentially be viewed as avenues for blackmailing or coercing an individual, thereby creating a security risk. Since Schroer had been open about her transsexuality, the court held this claim to be without merit. The Library's professed concern about Schroer's ability to maintain the necessary security clearance for the job were undermined by the Library's own lack of effort in determining whether Schroer's previously held clearance would be reciprocal, thereby applicable to her new job at the Library $(2008$, p. 301). In finding that transsexual individuals were entitled to the protection of the Civil Rights Act of 1964, the court asserted:

"Discrimination against a plaintiff who is transsexual-and therefore fails to act and/or identify with his or her gender-is no different from the discrimination directed against Ann Hopkins in Price Waterhouse who, in sex-stereotypical terms, did not act like a woman. Sex stereotyping based on a person's non-conforming behavior is impermissible discrimination, irrespective of the cause of that behavior" (2008, p. 304).

The court held that Schroer's claim against the Library of Congress should succeed on two different legal theories. First, the Library's adverse employment decision discriminated against Schroer because she did not fit Library officials' stereotypical conception of a woman triggered legal protection for Schroer under the Supreme Court's decision in Price Waterhouse. Secondly, Schroer was discriminated against "literally because ... of sex" (2008, p. 300).

Three years later, a judge for the Northern District of Georgia held that not only are transsexual individuals entitled to Title VII protection, but to discriminate against these individuals also violates the Equal Protection Clause of the United States Constitution (2010). In 2005, Elizabeth Glenn, then known as Glenn Morrison, was hired as an editor for the Georgia General Assembly's Office of Legislative Counsel where he would help draft bills for legislators, prepare revisions to the state code, and assist with the publication of the Georgia session laws. Prior to being hired, Glenn had to pass tests on grammar, spelling, proofreading, and vocabulary. On Halloween (October 31, 2006), Glenn came to work dressed as a woman. Her supervisor, Brumby, asked her to leave because, in Brumby's opinion, Glenn's appearance was in appropriate and, according to Brumby, "it's unsettling to think of someone dressed in women's clothing with male sexual organs inside that clothing" (2010, p. 1291).

Following the Halloween Day incident, Glenn returned to work, presenting as a man. A year later, Glenn informed his immediate supervisor, Beth Yinger, of his intention to undergo the transition to become 
physically female, to begin coming to work presenting as female, and to legally change his name. At this time, Glenn provided Yinger with a photograph of herself presenting as a woman. Brumby and another staff attorney at the Office of Legislative Council researched the legal issue involved with terminating an employee based on gender transition. Both discovered legal authority supporting both the illegality and legality of such termination. Despite adequate job performance, Brumby terminated Glenn solely based on her transition from being a man to being a woman. Later, Brumby attempted to defend his termination of Glenn by claiming a fear of litigation by other employees over Glenn's restroom usage (2010, p. 12921293).

Relying on the Supreme Court's holding in Price Waterhouse and the Sixth Circuit Court of Appeals' holding in Smith, the Glenn court concluded that although transgendered persons were not yet under the law considered a protected class, those transgendered persons who do not conform to standard sexual stereotypes are a protected class. The court asserted, "Transsexuality is not a bar to a sex stereotyping claim. Title VII is violated when an employer discriminates against any employee, transsexual or not, because he or she has failed to act or appear sufficiently masculine or feminine enough for an employer" (2010, p. 1300). Brumby's case was further weakened by evidence suggesting Brumby's concerns about Glenn's restroom usage did not arise until after she had been terminated.

\section{BOSTOCK V. CLAYTON COUNTY (2020)}

On June 15, 2020, the Supreme Court of the United States of America issued a towering decision by ruling that Title VII of the Civil Rights Act of 1964 included protections for individuals facing discrimination on the basis sexual orientation and/or transgender status. The Supreme Court consolidated cases from the Second Circuit, the Sixth Circuit, and the Eleventh Circuit and found that each plaintiff's employment had been adversely impacted and that sex had played a role in actions deemed discriminatory.

The decision stemmed from arguments presented to the court in October of 2019. Three different cases were argued on the same day.

1. Bostock v. Clayton County Georgia was a case concerning employment discrimination based on sexual orientation. Plaintiff, Gerald Bostock, was released from employment after expressing interest in a gay sports league while at work. Prior to argument at the Supreme Court, lower courts ruled in concert with the precedent established by the Eleventh Circuit's ruling that Title VII did not include protection from employment discrimination based upon sexual orientation.

2. Altitude Express v. Zarda was a case concerning employment discrimination based on sexual orientation. Don Zarda, a skydiving instructor who worked in Long Island, NY was fired after revealing his sexual orientation to a customer. Prior to the argument at the Supreme Court, the Second Circuit issued a precedent setting decision by ruling that adverse employment actions taken because of sexual orientation were acts of "sex discrimination" under Title VII.

3. In 2018, the 6th Circuit Court of Appeals decided the case of EEOC v. R.G. \& G.R. Harris Funeral Homes. Aimee Stephens, born a male named Anthony Stephens, was terminated from employment by the R.G \& G.R. Harris Funeral Homes after she informed the owner of the funeral home that she was transitioning from male to female and would represent and dress as a woman at work.

Stephens filed a complaint with the EEOC claiming unlawful sex discrimination under Title VII. After investigating the termination, the EEOC sued the funeral home for terminating Stephens's employment because of her transgender status and administering a discriminatory clothing allowance policy. The district court granted summary judgement in favor of the funeral home on both claims because the 6th Circuit had yet to provide any guidance about whether disparate dress codes violated Title VII and held that forcing Stephen's continued employment would constitute a violation of the Harris's sincerely held religious beliefs. Prior to argument at the Supreme Court, the United States Court of Appeals for the Sixth Circuit reversed the district court's grant of summary judgement. The appellate court found that businesses citing anti-LGBTQ religious beliefs are not exempted from complying with Title VII protections. 
In the six-justice majority ruling, the court held that the term "sex' does include sexual orientation and transgender status for the purpose of Title VII protections against workplace discrimination. In the majority opinion, Justice Gorsuch wrote, "In Title VII, Congress adopted broad language making it illegal for an employer to rely on an employee's sex when deciding to fire that employee" (2020). The Court went further: "We do not hesitate to recognize today a necessary consequence of that legislative choice: An employer who fires an individual merely for being gay or transgender defies the law" (2020, p. 1731). Additionally, Justice Gorsuch addressed the argument that Title VII was not intended or anticipated to address employees who were fired for being homosexual or transgender. He stressed that "is exactly the sort of reasoning this Court has long rejected" (2020, p. 1750). Gorsuch observed, "many, maybe most, applications of Title VII's sex provision were "unanticipated"' (2020, p. 1752) when Congress passed the law in 1964.

Lastly, Justice Gorsuch addressed what the opinion is not. He warns that this decision did not address religious or educational issues and re-focuses the decision of the Supreme Court to ... "an employer who fires an individual merely for being gay or transgender defies the law" (2020, p. 1734).

\section{DISCUSSION AND CONCLUSIONS}

Returning to the guiding question for this article, what did we get when we got sex? Clearly, the answer continues to evolve. With the Bostock decision, a major shift has occurred in the federal judiciary's interpretation of "discrimination on the basis of sex" as promulgated by Title VII of the 1964 Civil Rights Act. A majority of the Supreme Court adamantly believes the definition of "sex" under Title VII is much broader than was once thought. This new, broader interpretation of the 1964 statute has some obvious implications. First, employers across the nation will need to create and disseminate updated antidiscrimination statements and employee training. Many employers use mandatory training was a way to minimize the kinds of conduct that can give rise to Title VII claims. Annual training for all employees can provide needed reinforcement of identification of conduct that could result in liability for employees as well as the employer as well as tips on how to conduct business in ways that avoid proscribed conduct. The presents of a continuous training program can, in some cases, less liability of employers.

Second, how would the courts balance a religiously based institution's sincerely held beliefs that conflict with the new interpretation of Title VII? Perhaps the Court provided a hint:

Harris Funeral Homes did unsuccessfully pursue a RFRA-based defense in the proceedings below. In its certiorari petition, however, the company declined to seek review of that adverse decision, and no other religious liberty claim is now before us. So while other employers in other cases may raise free exercise arguments that merit careful consideration, none of the employers before us today represent in this Court that compliance with Title VII will infringe their own religious liberties in any way (2020, p. 1754).

Since Harris Funeral Homes did not raise the issue of a religious objection in its application for certiorari. Therefore, the Court never addressed that issue in its opinion. However, the Court admitted, "But worries about how Title VII may intersect with religious liberties are nothing new; they even predate the statute's passage. As a result of its deliberations in adopting the law, Congress included an express statutory exception for religious organizations" (2020, p. 1755). The court further states that for the government to burden an employer's religious beliefs, that action must pass strict scrutiny: "That statute [Religious Freedom Restoration Act of 1993, 42 U.S.C. $\S 2000$ bb] prohibits the federal government from substantially burdening a person's exercise of religion unless it demonstrates that doing so both furthers a compelling governmental interest and represents the least restrictive means of furthering that interest." The Court also admitted this issue should be decide by future cases: "But how these doctrines protecting religious liberty interact with Title VII are questions for future cases too" (2020, p. 1754). The balancing of sincerely-held religious beliefs and the Court's new, expanded view of Title VII must wait for its day in court. 


\section{REFERENCES}

Bostock v. Clayton County, Georgia, 140 S. Ct. 1731 - 1755. (2020).

Civil Rights Act of $1964 \S 7,42$ U.S.C. $\S 2000$ e et seq. (1964).

Etsitty v. Utah Transit Authority, 502 F. 3d 1215 - 1217 (10th Cir. 2007)

Frontiero v. Richardson, 411 US 677. (1973).

Glenn v. Brumby, 724 F. Supp. 2d 1284 - 1300 (N.D. Ga. 2010)

Graham v. Richardson, 403 US 365. (1971).

Holloway v. Arthur Andersen \& Co., 566 F. 2d 659 (9th Cir. 1977)

Hopkins v. Price Waterhouse, 618 F. Supp 1109 (D.C. Cir. 1985)

Hopkins v. Price Waterhouse, 825 F.2d 458 (D.C. Cir. 1987)

Lyng v. Castillo, 477 US 635. (1986).

Powell v. Read's, Inc., 436 F. Supp. 369 (Dist. Court, Dist. of Maryland 1977)

Price Waterhouse v. Hopkins, 490 US 228. (1989).

Schroer v. Billington, 577 F. Supp. 2d 293 - 304 (Dist. Court, Dist. of Columbia 2008)

Smith v. City of Salem, Ohio, 378 F. 3d 566 - 572(6th Cir. 2004)

Sommers v. Budget Marketing, Inc., 667 F. 2d 748 (Court of Appeals 8th Cir. 1982)

Ulane v. Eastern Airlines, Inc., 742 F.2d 1081 (7th Cir. 1984)

Voyles v. Ralph K. Davies Medical Center, 403 F. Supp. 456 (N.D. Cal. 1975) 